\title{
Late blowing of Cheddar cheese induced by accelerated ripening and ribose and galactose supplementation in presence of a novel obligatory heterofermentative nonstarter Lactobacillus wasatchensis ${ }^{1}$
}

\author{
Fatih Ortakci, ${ }^{* 2}$ Jeffery R. Broadbent, ${ }^{* 2}$ Craig J. Oberg, ${ }^{*} \dagger$ and Donald J. McMahon ${ }^{* 3}$ \\ *Western Dairy Center, Department of Nutrition, Dietetics, and Food Sciences, Utah State University, Logan 84322-8700 \\ †Microbiology Department, Weber State University, Ogden, UT 84408-2506
}

\begin{abstract}
Lactobacillus wasatchensis sp. nov. has been studied for growth and gas formation in a control Cheddar cheese and in cheese supplemented with $0.5 \%$ ribose, $0.5 \%$ galactose, or $0.25 \%$ ribose plus $0.25 \%$ galactose using regular and accelerated cheese ripening temperatures of 6 and $12^{\circ} \mathrm{C}$, respectively. Milk was inoculated with (1) Lactococcus lactis starter culture, or (2) Lc. lactis starter culture plus Lb. wasatchensis $\left(10^{4} \mathrm{cfu} /\right.$ $\mathrm{mL})$. In the control cheese with no added $L b$. wasatchensis, starter numbers decreased from $10^{7}$ initially to $\sim 10^{4} \mathrm{cfu} / \mathrm{g}$ over $23 \mathrm{wk}$ of ripening at $6^{\circ} \mathrm{C}$. When the cheese was ripened at $12^{\circ} \mathrm{C}$, or if $L b$. wasatchensis was added, the final starter counts were 1 log lower. In contrast, nonstarter lactic acid bacteria in the cheese increased from $<10^{2} \mathrm{cfu} / \mathrm{g}$ at press to $10^{6}$ to $10^{7} \mathrm{cfu} / \mathrm{g}$ after $23 \mathrm{wk}$, with higher numbers being observed with ripening at $12^{\circ} \mathrm{C}$. In cheese with no added $L b$. wasatchensis, levels of $L b$. wasatchensis were initially below the enumeration threshold but counts of up to $10^{3} \mathrm{cfu} / \mathrm{g}$ were detected after 23 wk. When the cheese was inoculated with Lb. wasatchensis, it could be enumerated throughout ripening, with final levels at 23 wk being dependent on whether ribose had been added to the cheese curd. With added ribose (with or without added galactose), Lb. wasatchensis grew to $10^{7}$ to $10^{8} \mathrm{cfu} / \mathrm{g}$ after $23 \mathrm{wk}$, whereas without added ribose it was 1 log lower. In all cheeses with added Lb. wasatchensis, greater gas formation was observed at $12{ }^{\circ} \mathrm{C}$, with most gas production occurring after $\sim 16$ wk. Very little gas

\footnotetext{
Received February 13, 2015.

Accepted June 25, 2015.

${ }^{1}$ In a previous paper (Ortakci et al., 2015), this bacteria was

${ }^{2}$ Current address: DuPont Nutrition and Health, 3322 Agriculture

${ }^{3}$ Corresponding authors: Jeff.Broadbent@usu.edu and Donald.
} called Lactobacillus wasatchii. The accepted name is Lactobacillus wasatchensis (Oberg et al., 2015), in homage to the Wasatch mountain range running between Weber State University and Utah State University, where this bacteria was first isolated and characterized. Drive, Madison, WI. McMahon@usu.edu
\end{abstract}

production was detected in cheese without added $L b$. wasatchensis ripened at $12^{\circ} \mathrm{C}$ or in cheese with added Lb. wasatchensis ripened at $6^{\circ} \mathrm{C}$. Adding a combination of ribose and galactose caused more gas formation, putatively because of the ability of $L b$. wasatchensis to co-utilize both sugars and grow to high numbers, and then produce gas from galactose as ribose levels were depleted. Even without sugar supplementation, gas was observed in cheese with added $L b$. wasatchensis after 16 wk. We also observed that $L b$. wasatchensis could grow to high cell densities when grown in carbohydraterestricted broth containing lactococcal cell lysate. This suggests that during cheese ripening, lysis of starter bacteria provides sufficient substrates (such as ribose) to allow growth of $L b$. wasatchensis and, if fermentable hexose is available, the cheese will become gassy. We conclude that $L b$. wasatchensis is a previously undetected contributor to late gas formation in Cheddar cheese and the defect is more pronounced when elevated ripening temperatures are used.

Key words: nonstarter, lactic acid bacteria, gas, cheese, starter autolysis

\section{INTRODUCTION}

Ripening cheese at elevated temperatures is technically the simplest method to accelerate maturation, and the lower refrigeration costs may provide overall savings to the producer (Wilkinson, 1993; Folkertsma et al., 1996). However, late gas formation ("gassy defect") in Cheddar cheese has been a recurring problem for over $100 \mathrm{yr}$ and this defect continues to be one of the main concerns during accelerated ripening (Van Slyke and Hart, 1903; Mullan, 2000). This defect is manifest as openness of cheese texture (slits or cracks) or "blown wrappers" without any texture change in cheeses aged longer than 3 mo (Laleye et al., 1987). Gassy defect tends to be sporadic and recurrent and has probably been experienced at most cheese-making plants (Mullan, 2000). The slits, cracks, or voids caused by gassy defect in cheese are not usually evident until the cheese 
is graded unless the cheese pack is loose. Even though this textural defect may not create a specific sensory defect, it may result in the inability of a cheese converter to cut the blocks with uniformity and also affects the slicing ability of the cheese. If the defect is severe, the block will crumble upon cutting, which can increase cutting losses from 10\% (nondefective) up to 50\% (Elliott et al., 1981; Donnely et al., 2014). In addition, the time and money spent on the aging process is lost, as such cheese is downgraded and sold at a lower price (Martley and Crow, 1996; Golnazarian, 2001).

Gassy defect in cheese has been associated with poor sanitation (usually observed as early gas formation) and germination of Clostridium spores (late blowing; Fox et al., 1990; McSweeney and Fox, 2004). In properly manufactured Cheddar cheese with a $\mathrm{pH}<5.4$ and salt-in-moisture $(\mathbf{S} / \mathbf{M})$ content $>4.0 \%$ (Lawrence et al., 2004), gassiness has been attributed to obligate heterofermentative ( $\mathbf{O H F}$ ) nonstarter lactobacilli species such as Lactobacillus brevis and Lactobacillus fermentum (Sherwood, 1939; Laleye et al., 1987, 1990). It has often been difficult to identify the cause of gassiness, however, and Elliott et al. (1981) linked gassy defect in Cheddar cheese to an unidentified and slow-growing bacterium.

Our group has isolated a novel slow-growing OHF species, Lactobacillus wasatchensis, from a "gassy" Cheddar cheese manufactured at Utah State University (Oberg et al., 2015). We reported that Lb. wasatchensis produces gas from hexose sugars and can co-utilize ribose and galactose (Ortakci et al., 2015). These are potential substrates for nonstarter lactic acid bacteria (NSLAB) in Cheddar cheese (Tinson et al., 1982; Thomas, 1987; Rapposch et al., 1999; Michel and Martley, 2001). We also showed that Lb. wasatchensis is able to grow under salt and $\mathrm{pH}$ conditions typical of Cheddar cheese ( 4 to $5 \% \mathrm{~S} / \mathrm{M}, \sim \mathrm{pH} 5.2$ ), and that there is potential for some survival of $L b$. wasatchensis during HTST pasteurization (Ortakci et al., 2015).

The ability of $L b$. wasatchensis to readily utilize both ribose and galactose, to grow at cheese ripening temperatures, and to survive in the relatively harsh environment of cheese led us to hypothesize that $L b$. wasatchensis is a contributor to late gas blowing and textural defects in Cheddar cheese (Ortakci et al., 2015). The aims of this work were to confirm that gas formation occurs in Cheddar cheese when Lb. wasatchensis is present, and to examine the effect of temperature (6 or $12^{\circ} \mathrm{C}$ ) and substrate availability (ribose and galactose) on this phenomenon. Using these experimental parameters, we monitored the microbiota of the cheese for $L b$. wasatchensis, starter lactococci, and NSLAB, as well as gas formation throughout $23 \mathrm{wk}$ of ripening.

\section{MATERIALS AND METHODS}

\section{Bacteria and Growth}

Working cultures of Lb. wasatchensis WDC-04 (Oberg et al., 2015) were prepared from frozen stocks stored at $-80^{\circ} \mathrm{C}$ by sequential transfer twice into de Man, Rogosa, and Sharpe (MRS; Becton Dickinson Inc., Sparks, MD) broth containing $1.5 \%$ (wt/vol) ribose (R; donated by Bioenergy Life Science Inc., Ham Lake, $\mathrm{MN}$ ), in which the cultures were incubated anaerobically using GasPak EZ (Becton Dickinson Inc.) at $23^{\circ} \mathrm{C}$ for $40 \mathrm{~h}$. Cells for the cheese-making experiments were propagated in $400 \mathrm{~mL}$ of $\mathrm{MRS}+\mathrm{R}$ for $40 \mathrm{~h}$ at $23^{\circ} \mathrm{C}$. Cells were harvested by centrifugation at $6,000 \times g$ for $10 \mathrm{~min}$ at $4^{\circ} \mathrm{C}$, washed twice with sterile $0.1 \%$ (wt/vol) peptone water, and then collected again by centrifugation. Concentration of cell suspensions was determined by anaerobic spread plate counts on $\mathrm{MRS}+\mathrm{R}$ agar after $5 \mathrm{~d}$ at $23^{\circ} \mathrm{C}$. The cell suspensions were subsequently used in cheese-making experiments after proper dilutions were made to reach desired numbers in cheese milk.

Frozen pellets of Lactococcus lactis ssp. lactis/cremoris (DVS850, Chr. Hansen Inc., Milwaukee, WI) suspended in peptone water (optical density at $600 \mathrm{~nm}$, $\mathrm{OD}_{600}$, of $\sim 0.9$ ) was inoculated into $750 \mathrm{~mL}$ of $\mathrm{M} 17$ broth (Becton Dickinson Inc.) supplemented with 1\% lactose (M17-L; Sigma-Aldrich Inc., St. Louis, MO) and incubated at $30^{\circ} \mathrm{C}$ for $24 \mathrm{~h}$ under aerobic conditions. The cells were then harvested by centrifugation $(7,500$ $\times g ; 10 \mathrm{~min} ; 4^{\circ} \mathrm{C}$ ), washed twice in $50 \mathrm{~mL}$ of sterile phosphate buffer and then suspended in $10 \mathrm{~mL}$ of sterile phosphate buffer. A 0.1-mL aliquot was diluted and plated on M17-L agar to enumerate starter numbers (Branen and Keenan, 1969; Thomas, 1987; Rapposch et al., 1999). The cell suspensions were stored at $-80^{\circ} \mathrm{C}$ until used in cell-free extract experiments.

\section{Cheese Making}

Fresh bovine milk was obtained from the George B. Caine Dairy Research and Teaching Center (Wellsville, UT) and transported to the Gary Haight Richardson Dairy Products Laboratory at Utah State University (Logan). The milk was standardized to a protein-to-fat ratio of 0.84 and pasteurized at $73^{\circ} \mathrm{C}$ for $15 \mathrm{~s}$; then, 273 $\mathrm{kg}$ was transferred into each of 2 open stainless steel vats (which had previously been cleaned and heat sanitized for $30 \mathrm{~min})$. Both batches of milk were warmed to $31^{\circ} \mathrm{C}$, and then $0.2 \mathrm{~g} / \mathrm{kg}$ of frozen pellets containing Lc. lactis ssp. lactis/cremoris starter culture DVS850 were added. To one of the vats, $10^{4} \mathrm{cfu} / \mathrm{mL}$ of $L b$. 
wasatchensis was also added, and the milk was allowed to ripen for $20 \mathrm{~min}$ in both vats. Then, $0.12 \mathrm{~mL} / \mathrm{kg}$ of a $32 \%$ (wt/wt) $\mathrm{CaCl}_{2}$ solution (Nelson-Jameson Inc., Marshfield, WI), $0.13 \mathrm{~mL} / \mathrm{kg}$ of single-strength annatto (DSM Food Specialties USA Inc., Eagleville, PA) and $0.16 \mathrm{~mL} / \mathrm{kg}$ of double-strength ( $\sim 650$ international milk clotting units/mL) chymosin rennet (Maxiren; DSM Food Specialties USA Inc.) were added, and the milk was allowed to set undisturbed for $30 \mathrm{~min}$. After cutting and healing, the curd/whey mixtures were stirred for $10 \mathrm{~min}$, heated to $39^{\circ} \mathrm{C}$ over $35 \mathrm{~min}$, and then stirred for another $10 \mathrm{~min}$. The curd was stirred until a curd $\mathrm{pH}$ of 6.3 was reached with partial whey drainage. The remaining whey was then drained and curd was allowed to mat together, cut into slabs, and cheddared for approximately $160 \mathrm{~min}$ until the curd $\mathrm{pH}$ reached 5.4. Curd was milled and then salted $(30 \mathrm{~g} / \mathrm{kg}$ of curd $)$ in 3 applications with 5 min between each application. Salted curd from each vat was separated into four $7-\mathrm{kg}$ portions in open plastic containers. One portion served as a control with no sugar added, whereas to the other portions was added (wt/wt basis) $0.5 \%$ ribose, $0.5 \%$ galactose (Alfa Aesar Inc., Ward Hill, MA), or 0.25\% ribose plus $0.25 \%$ galactose. The curd was mixed for 5 min and then placed into plastic hoops and pressed overnight $\left(140 \mathrm{kPa}, \sim 18 \mathrm{~h}, \sim 20^{\circ} \mathrm{C}\right)$. The cheese was recovered from the hoops and each block cut into 10 pieces of $\sim 600 \mathrm{~g}$ each, and the pieces were individually vacuum packaged. Five pieces were stored at $6^{\circ} \mathrm{C}$ and 5 at $12^{\circ} \mathrm{C}$. Cheese-making trials were conducted in triplicate.

\section{Microbial Enumerations}

At $0,8,16$, and 23 wk, cheese samples (11 g) were collected from the interior of each cheese and homogenized in $99 \mathrm{~mL}$ of sterilized $2 \%$ sodium citrate (warmed to $45^{\circ} \mathrm{C}$ ) using a Stomacher 400 Circulatory laboratory blender (Seward Laboratory Systems Inc., Bohemia, NY) set for $3 \mathrm{~min}$ at $230 \mathrm{rpm}$ (Broadbent et al., 2013). Serial dilutions were prepared in $0.1 \%$ sterile peptone water, and then lactococcal starter was enumerated on M17-L agar after aerobic incubation at $30^{\circ} \mathrm{C}$ for $24 \mathrm{~h}$. The method of Oberg et al. (2011) was used for enumerating NSLAB on MRS agar supplemented with $2 \mu \mathrm{g} /$ $\mathrm{mL}$ vancomycin $(\mathbf{V})$ incubated anaerobically at $37^{\circ} \mathrm{C}$ for $48 \mathrm{~h}$. Such relatively fast-growing NSLAB counts were designated as NSLAB37, and Lb. wasatchensis does not grow quickly enough to be enumerated at 48 h. Like many NSLAB, Lb. wasatchensis is resistant to vancomycin but does not form colonies on MRS-V at $37^{\circ} \mathrm{C}$ within $48 \mathrm{~h}$ (data not shown).

The mean $\log$ numbers from the 3 replicates were plotted against storage time and a trend line fitted to each set of data based on the highest $\mathrm{R}^{2}$ obtained. The time (week) when the NSLAB37 trend line equaled and then surpassed the starter trend line was considered the crossover time (Oberg et al., 2011). All plate counts were performed in duplicate using the spread plate method.

Enumeration of Lb. wasatchensis. Nonstarter lactic acid bacteria were also enumerated on MRS-V agar supplemented with $1.5 \%$ ribose (MRS-R-V) after $48 \mathrm{~h}$ of anaerobic incubations at $23^{\circ} \mathrm{C}$, and these counts were designated as NSLAB23. After obtaining counts for NSLAB23 after $48 \mathrm{~h}$ of incubation at $23^{\circ} \mathrm{C}$ on MRS-R-V medium and marking all the visible colonies ( $\sim 1.5 \mathrm{~mm}$ diameter $)$, the plates were incubated anaerobically at $23^{\circ} \mathrm{C}$ for an additional $72 \mathrm{~h}$. By this time, Lb. wasatchensis forms noticeable colonies $(\sim 1$ $\mathrm{mm}$ diameter), which enables differential enumeration of this organism from other NSLAB23 colonies provided the number of $L b$. wasatchensis colonies is within $\sim 1.5$ $\log$ of the NSLAB23 counts.

\section{Cell-Free Extract and Growth}

The cell suspensions containing $\sim 10^{10} \mathrm{cfu} / \mathrm{mL}$ of starter lactococci were divided into $0.5-\mathrm{mL}$ aliquots and placed into $2-\mathrm{mL}$ screw-cap tubes that contained $0.5 \mathrm{~g}$ of sterile $100-\mu \mathrm{m}$-diameter glass beads (BioSpec Products, Bartlesville, OK). Cells were disrupted in a Mini-Beadbeater (Biospec Products) at a speed setting of homogenize, in 12 bursts of $30 \mathrm{~s}$ each, with 2 -min intermittent cooling periods in an ice bath between bursts. After centrifugation $\left(4^{\circ} \mathrm{C}, 15 \mathrm{~min}, 21,130 \times g\right)$, the supernatant was collected and protein concentration determined with a modified Lowry Protein assay kit (Pierce/ThermoScientific, Rockford, IL) using BSA (2 $\mathrm{mg} / \mathrm{mL}$ stock solution; Pierce) as the standard. To determine the efficacy of lysis, $0.1 \mathrm{~mL}$ of the lysate was plated on M17-L agar and incubated at $30^{\circ} \mathrm{C}$ for $24 \mathrm{~h}$. The remaining supernatant was filter sterilized (0.2$\mu \mathrm{m}$ pore size membranes) and $1 \mathrm{~mL}$ of the filtrate was mixed with $0.2 \mathrm{~mL}$ of 5 -fold-concentrated carbohydratefree MRS (Anonymous, 2015). This lysate solution was inoculated with $20 \mu \mathrm{L}$ of $\mathrm{Lb}$. wasatchensis (previously sub-cultured twice in MRS+R) and incubated at $23^{\circ} \mathrm{C}$ for $10 \mathrm{~d}$ under anaerobic conditions. Growth of $L b$. wasatchensis was monitored by $\mathrm{OD}_{600}$ measurements taken at 0 and $10 \mathrm{~d}$. A control was prepared by adding 1 $\mathrm{mL}$ of sterile ultrapure water instead of lysate. Growth studies on starter lysate were performed in triplicate.

\section{Cheese Gas Measurements}

Gas production during storage of vacuum-packaged cheese was measured by the extent of loosening of the 
plastic bag around the cheese. After pressing, similar sized $(\sim 600 \mathrm{~g})$ blocks of cheese were inserted into plastic bags (QME355 3.5 mil; Vilutis and Co. Inc., Frankfurt, IL) and the bag vacuum-sealed $\sim 5 \mathrm{~cm}$ distance from the cheese block. Ten blocks were packaged for each treatment with 5 stored at each temperature $\left(6\right.$ and $\left.12^{\circ} \mathrm{C}\right)$. The vacuum-packaged cheese was then visually examined and on the side of the pack that was just sealed, a d-0 line was drawn along the pack at the position where it was tightly pulled against the cheese. After 8,16 , and $23 \mathrm{wk}$, the cheese packs were examined for gas production and loosening of the package. If the pack was no longer tightly held against the cheese, the pack was manually pulled away from the cheese block (on the same side that was initially marked) as much as possible. A new line was then drawn on the bag at the point at which the 2 layers of the bag were still held together by any residual vacuum inside the bag. The distance between that line and the $\mathrm{d}-0$ line was then measured and used as an expression of relative gas formation. The more gas produced, the further the plastic bag could be pulled away from the cheese block. When sufficient gas production had occurred inside the cheese pack so that there was no longer any residual vacuum (compared with atmospheric pressure), the cheese pack could be pulled the full $5 \mathrm{~cm}$ from the cheese to the seal. The distance the pack could be pulled was calculated in relation to this maximum distance and expressed as relative gas production. All available packs were tested for relative gas production before opening the packs and sampling the cheese for microbial analysis. For each treatment, 4 packs were tested at 8 wk, 3 at 16 wk, and 2 at 23 wk of storage.

\section{Chemical Analysis}

Proximate composition of the cheeses was determined after approximately $3 \mathrm{~d}$. Moisture content was measured by weight loss using $\sim 3.7 \mathrm{~g}$ of grated cheese in a microwave moisture analyzer (model SMART System 5; CEM Corporation, Matthews, NC) at $100 \%$ power with an endpoint setting of $<0.4 \mathrm{mg}$ of weight change over $2 \mathrm{~s}$. Fat content was measured by a modified Babcock method (Richardson, 1985). Salt was measured by homogenizing grated cheese with distilled water for 4 min at $260 \mathrm{rpm}$ in a Stomacher. The slurry was filtered through a Whatman \#1 filter paper (Whatman International Ltd., Maidstone, UK), and the filtrate was analyzed for sodium chloride using a chloride analyzer (model 926, Corning, Medfield, MA). The S/M content was calculated as salt/(moisture + salt) and expressed as percentage.

\section{Sugar and Organic Acid Analysis}

Cheese samples from each treatment were analyzed by HPLC for lactose, galactose, lactic acid, acetic acid, citric acid, propionic acid, pyruvic acid, formic acid, and orotic acid at d 0 and after 16 wk of ripening as described by Phadungath (2011). For the sample preparation, about $5 \mathrm{~g}$ of cheese was manually homogenized for $90 \mathrm{~s}$ with $10 \mathrm{~mL}$ of $0.013 \mathrm{~N}$ sulfuric acid (Fisher Scientific, Fair Lawn, NJ) at $65^{\circ} \mathrm{C}$ using a high shear Omni mixer-homogenizer (model 17105, Omni International, Waterbury, CT). The extract was centrifuged (Jouan CR4-12 Centrifuges, Jouan Inc., Winchester, VA) at $7,000 \times g$ for $10 \mathrm{~min}$ at $4^{\circ} \mathrm{C}$. The samples were held at $4^{\circ} \mathrm{C}$ for $20 \mathrm{~min}$ to solidify the fat layer, which was removed with a spatula, and the supernatant was filtered through Whatman \#4 filter paper. A $0.5-\mathrm{mL}$ aliquot of filtered supernatant was poured into a $0.5-\mathrm{mL}$ Microcon (Millipore Corporation, Bedford, MA) centrifugal filter device with a molecular weight cut-off of 3,000 Da and micro-centrifuged (Jouan A14 Microcentrifuge) at $14,000 \times g$ for $20 \mathrm{~min}$ to remove soluble peptides. The filtrate collected from the micro-centrifuge was directly injected into the HPLC system.

The HPLC system (Beckman Coulter Inc., Fullerton, CA) was equipped with a photodiode array detector set at $210 \mathrm{~nm}$, and data processing software (System Gold HPLC, 32 Karat Software, Beckman Coulter Inc.). The system was externally equipped with an intelligent refractive index detector (model RI-2031, Jasco Inc., Easton, MD), and a column heater (model 6301, Alltech Associates Inc., Deerfield, IL). The column used for separation of the analytes was a Rezex ROA-organic acid $\mathrm{H}^{+}$column $(300 \times 7 \mathrm{~mm}, 8 \mu \mathrm{m}$, Phenomenex, Torrance, CA) held at $65^{\circ} \mathrm{C}$, with a cation $\mathrm{H}^{+}$ microguard cartridge (Bio-Rad Laboratories, Hercules, $\mathrm{CA}$ ). The analysis was performed isocratically at a 0.6 $\mathrm{mL} / \mathrm{min}$ flow rate using $0.013 N$ sulfuric acid as the mobile phase. Quantification of analytes was based on the external standard method described by Upreti et al. (2006b).

\section{Experimental Design}

The experiment was conducted as a randomized block with addition of $L b$. wasatchensis as a whole plot factor, sugar addition as split plot factor, temperature as splitsplit plot factor, and ripening time as split-split-split plot factor. Statistical analysis of the effect of added sugar, storage time, temperature, and $L b$. wasatchensis addition was performed using PROC GLIMMIX in SAS (version 9.1; SAS Institute Inc., Cary, NC) with Type III test of fixed effects. Differences between means were 
Table 1. The effect of adding ribose or galactose, ripening temperature $\left(6,12^{\circ} \mathrm{C}\right)$, and time $(0,16 \mathrm{wk})$, and inoculated Lactobacillus wasatchensis (LBW) on the sugar and organic acid contents of Cheddar cheese

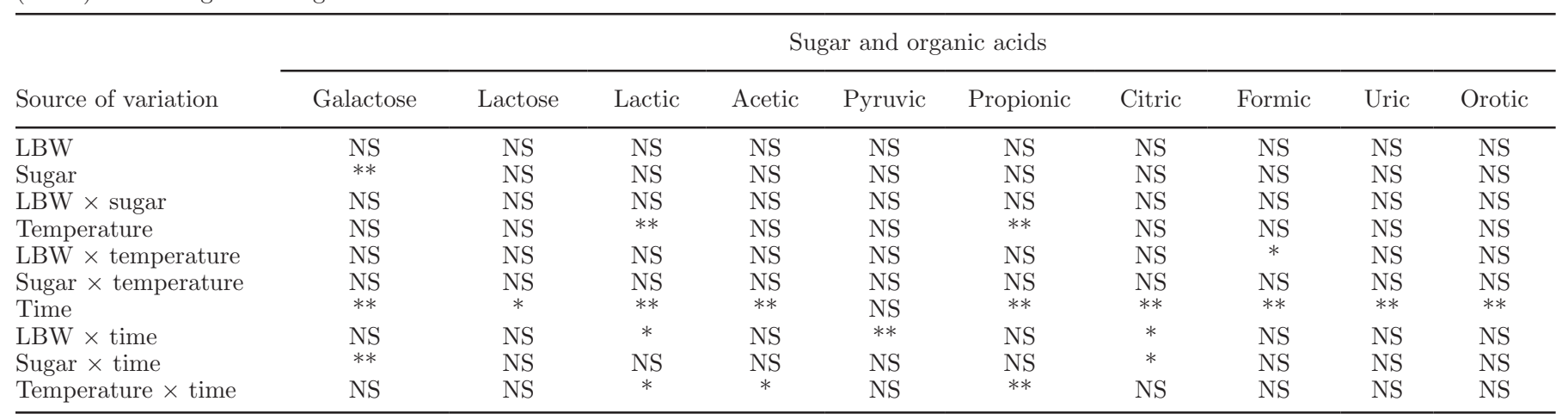

${ }^{*} P<0.05 ; * * P<0.01 ; \mathrm{NS}=P>0.05$.

determined using Tukey least squares means. Significance was declared at $P<0.05$.

\section{RESULTS AND DISCUSSION}

\section{Initial Cheese Composition}

Addition of $L b$. wasatchensis to cheese milk or sugar supplementation of curd did not significantly $(P>$ 0.05 ) affect the moisture, salt, $\mathrm{S} / \mathrm{M}, \mathrm{pH}$, fat, lactose, or citrate levels of cheese (Table 1 ). Thus, those values were pooled across treatments. The pooled means of moisture and fat were $37.0 \pm 0.16 \%$ and $32 \pm 0.1 \%$ respectively, which are typical for Cheddar cheese. The pooled mean salt content was $2.14 \pm 0.03 \%$ with $\mathrm{S} / \mathrm{M}$ of $5.47 \pm 0.07 \%$, which is higher compared with mean $\mathrm{S} / \mathrm{M}$ levels in retail Cheddar cheese $(4.3 \%)$ in the United States (Agarwal et al., 2011). However, $\mathrm{S} / \mathrm{M}$ was in the range considered appropriate for goodquality aged cheese (4 to $6 \% \mathrm{~S} / \mathrm{M}$ ) as described by Lawrence et al. (1993). The $\mathrm{pH}(5.38 \pm 0.03)$ was at the high end of expected range (5.0 to 5.4; Lawrence et al., 2004), but this was not unexpected as higher $\mathrm{pH}$ (i.e., $>5.35$ ) in Cheddar cheese typically occurs when salt concentrations are $>2.0 \%$ or with $\mathrm{S} / \mathrm{M} \geq 5.7 \%$ (Turner and Thomas, 1980; Thomas and Pearce, 1982; Lane et al., 1997). The higher retention of salt in our experiment may have resulted from the longer time allowed after salting and before pressing while the sugars were being added. In previous experiments, the same make procedure had produced cheeses with 1.4 to $1.8 \%$ salt (Oberg et al., 2011; Broadbent et al., 2013: McMahon et al., 2014). Mean initial lactose content was $0.42 \pm$ $0.024 \%$ and citrate content was $0.13 \pm 0.01 \%$ (Table 2). Initial lactic acid content was $\sim 1 \%$, which is lower than previously reported by McSweeney and Fox (2004) and McMahon et al. (2014), who found 1.4 to $1.5 \%$ lactic acid after the pressing of Cheddar cheese. Lower lactic acid levels correspond to cheese having high S/M levels and higher $\mathrm{pH}$.

Initial galactose content of cheese was significantly different based upon sugar supplementation to the curd (Table 1). Ripening time and the interaction of time and sugar addition were also significant. In contrast, lactose content was only significantly influenced by ripening time (Table 1). It is usually assumed that lactose is consumed during ripening, but having relatively high $\mathrm{S} / \mathrm{M}(\sim 6 \%)$ can reduce the rate of lactose utilization by lactococcal starter cultures in cheese to almost zero (Turner and Thomas, 1980). Persistence of lactose in Cheddar cheese during storage was also shown by Fox et al. (1998), who reported the continued presence of lactose after 36 wk of ripening. Lactose content after 23 wk of ripening remained at $0.36 \pm 0.02 \%$.

Galactose levels in cheese were not significantly influenced by addition of $L b$. wasatchensis or by ripening temperature, and pooled mean values are presented in Table 3. Initial galactose content of the control cheese was $0.023 \%$, with no significant change occurring during $16 \mathrm{wk}$ of ripening. Adding ribose to the cheese curd caused no significant difference in initial galactose levels compared with the control cheese, but after $16 \mathrm{wk}$ of storage, only $0.003 \%$ galactose remained $(P<0.05)$. This implies that a faster rate of galactose utilization occurs when more ribose than normal is present in cheese and agrees with our previous findings (Ortakci et al., 2015) that Lb. wasatchensis appears to concomitantly co-utilize ribose and galactose to maximize energy production and cell growth. Initial galactose levels for cheeses in which 0.5 and $0.25 \%$ galactose was added to the cheese curd were 0.238 and $0.125 \%$, respectively. This suggests that half of the galactose added to the curd after salting was lost in the expelled whey during pressing. During ripening, the level of galactose in these cheeses decreased to levels similar to those of the control cheese 


\section{Starter Lactococci and NSLAB During Ripening}

Starter lactococci numbers in cheese were influenced by ripening temperature, ripening time, and whether or not the milk had been inoculated with $L b$. wasatchensis (Table 4). We detected no direct effect of adding $L b$. wasatchensis on lactococci numbers but there was a significant interaction with time and temperature as the main effect was not significant. Adding ribose or galactose (separately or together) did not significantly affect lactococcal numbers and, therefore, pooled means across all sugar treatments were compared. Lactococcal numbers decreased when high numbers of $L b$. wasatchensis were initially present and the rate and extent of decrease was dependent on ripening temperature (Figure 1).

The NSLAB numbers (meaning the fast-growing lactobacilli enumerated at $23^{\circ} \mathrm{C}$ and $37^{\circ} \mathrm{C}$, not including Lb. wasatchensis) were only influenced by ripening time and temperature (Table 4). Adding ribose or galactose had no significant effect on NSLAB numbers, nor were there any significant interactions between sugar addition and ripening temperature or time. Adding $L b$. wasatchensis was only significant as an interaction with ripening time and as a 3-way interaction with time and temperature. Therefore, NSLAB numbers were pooled over sugar and $L b$. wasatchensis addition, and compared over ripening temperature and time as well as whether they were enumerated at $37^{\circ} \mathrm{C}$ on $\mathrm{MRS}-\mathrm{V}$ agar or at $23^{\circ} \mathrm{C}$ on MRS-R-V agar (Figure 2). The influence of ripening temperature and time on both lactococci and NSLAB has been well demonstrated (Peterson and Marshall, 1990; Wilkinson et al., 1994; Fox et al., 1998; Oberg et al., 2011; McMahon et al., 2014).

The best fit of the data was most often obtained using power or log trend lines, especially during the first few weeks of aging when the greatest growth of the NSLAB and greatest decrease in starter culture counts occurred. The crossover time when NSLAB numbers became greater than lactococci numbers occurred in all cheeses during the first $8 \mathrm{wk}$ of ripening at either temperature. Based on the fitted trend lines, it appears that crossover time was achieved around 4 and 8 wk of ripening at 12 and $6^{\circ} \mathrm{C}$, respectively (Figure 1). This is sooner than previously reported NSLAB crossover times $\geq 4$ mo of ripening of Cheddar cheese made with the same starter culture (McMahon et al., 2014). This could be due to the differences in S/M contents, as McMahon et al. (2014) reported levels around 4.7\% S/M, whereas the $\mathrm{S} / \mathrm{M}$ levels in the present study were $5.5 \%$.

Lactococcus lactis starter cultures, along with many other lactic acid bacteria, are sensitive to the salt concentration in cheese. Upreti et al. (2006a) reported that a $\mathrm{S} / \mathrm{M}$ concentration in cheese above $4.5 \%$ results 
Table 3. Pooled means of galactose concentrations (\%) at 0 and 16 wk in cheese supplemented with no sugar (control), $0.5 \%$ ribose $(0.5 \mathrm{R}), 0.5 \%$ galactose $(0.5 \mathrm{G})$, or $0.25 \%$ ribose plus $0.25 \%$ galactose $(0.25 \mathrm{R}+0.25 \mathrm{G})$

\begin{tabular}{|c|c|c|c|c|c|c|c|c|}
\hline \multirow[b]{2}{*}{ Item } & \multicolumn{2}{|c|}{ Control } & \multicolumn{2}{|c|}{$0.5 \mathrm{R}$} & \multicolumn{2}{|c|}{$0.5 \mathrm{G}$} & \multicolumn{2}{|c|}{$0.25 \mathrm{R}+0.25 \mathrm{G}$} \\
\hline & $0 \mathrm{wk}$ & $16 \mathrm{wk}$ & 0 wk & $16 \mathrm{wk}$ & $0 \mathrm{wk}$ & $16 \mathrm{wk}$ & $0 \mathrm{wk}$ & $16 \mathrm{wk}$ \\
\hline Mean & $0.023^{\mathrm{cd}}$ & $0.048^{\mathrm{cd}}$ & $0.061^{\mathrm{bc}}$ & $0.003^{\mathrm{d}}$ & $0.238^{\mathrm{a}}$ & $0.076^{\mathrm{bc}}$ & $0.125^{\mathrm{b}}$ & $0.078^{\mathrm{bc}}$ \\
\hline $\mathrm{SE}$ & 0.0221 & 0.0246 & 0.0185 & 0.0199 & 0.0221 & 0.0205 & 0.0277 & 0.0204 \\
\hline
\end{tabular}

${ }^{\mathrm{a}-\mathrm{d}}$ Means with the same superscript letters were not significantly different from one another, $\mathrm{n}=12, \alpha=0.05$.

in a more rapid decrease in starter lactococci during initial ripening. Conversely, starter bacteria numbers can remain at a higher concentration in the aging cheese if the $\mathrm{S} / \mathrm{M}$ is low ( $<4.5 \%$; Lane et al., 1997), resulting in longer crossover times. Having higher S/M levels in cheese impairs the fermentation of lactose to lactic acid by starter bacteria so there is less decrease in $\mathrm{pH}$ after pressing (Olson and Johnson, 1990), and an elevated salt concentration can continue to affect the growth of bacteria during cheese storage. Although the typical S/M concentration in Cheddar cheese (4.0 to $5.5 \%$ ) is not sufficient to prevent all microbial growth, in combination with a low $\mathrm{pH}$ and refrigerated ripening temperature, it prevents growth of bacterial pathogens and influences LAB populations (McMahon et al., 2014). A high salt concentration also decreases lactose metabolism by starter lactococci, leaving more residual lactose available to be used by NSLAB during ripening (Turner and Thomas, 1980). Thus, it is not surprising that with the higher $\mathrm{S} / \mathrm{M}$ content of our cheeses there was a shorter crossover time, with NSLAB numbers being higher than lactococci by $\leq 2$ mo of ripening (Figure $1)$.

The total reductions in the numbers of starter lactococci during ripening at 12 or $6^{\circ} \mathrm{C}$ over 23 wk were similar, approximately 4.5 and $4 \mathrm{log}$, respectively. As stated above, we detected a significant interaction between addition of $L b$. wasatchensis and ripening time as well as a significant $L b$. wasatchensis $\times$ time $\times$ temperature interaction $(P<0.05$; Table 4$)$. After 8 wk of ripening at $12^{\circ} \mathrm{C}$, starter lactococci numbers were significantly lower in cheese containing added $L b$. wasatchensis compared with the control cheese (i.e., cheese milk not inoculated with $L b$. wasatchensis, $P<0.05$; Figure 1). At $6^{\circ} \mathrm{C}$, however, starter lactococci counts were the same $(P>0.05)$ in both cheeses although the trend lines also showed a slightly faster decrease in cheese with added Lb. wasatchensis.

As ripening progressed, starter lactococci numbers were similar in control and $L b$. wasatchensis-treated cheese at $12^{\circ} \mathrm{C}$, whereas at $6^{\circ} \mathrm{C}$ they were significantly higher in the control cheese (Figure 1). Having a greater reduction in lactococci numbers during ripening when $L b$. wasatchensis had been added to the milk, corresponds with slower acid development and longer cheese-making times in these cheeses, even though the same amount of starter was used in all cheeses. We do not know the basis for this faster decrease in starter lactococci counts when high numbers of $L b$. wasatchensis were present, as no genes encoding antimicrobial compounds have been found in the genome of $L b$. wasatchensis (F. Ortakci and J. Broadbent, unpublished data).

Along with the faster decrease in lactococcal counts, NSLAB counts (both NSLAB23 and NSLAB37) in-

Table 4. The effect of adding ribose or galactose, ripening temperature $\left(6\right.$ or $\left.12^{\circ} \mathrm{C}\right)$, and time $(0,8,16,23$ wk $)$ on relative gas formation and on the numbers of starter lactococci, nonstarter lactic acid bacteria enumerated at $23^{\circ} \mathrm{C}$ (NSLAB23) or $37^{\circ} \mathrm{C}$ (NSLAB37), and added Lactobacillus wasatchensis (LBW) in Cheddar cheese ripening

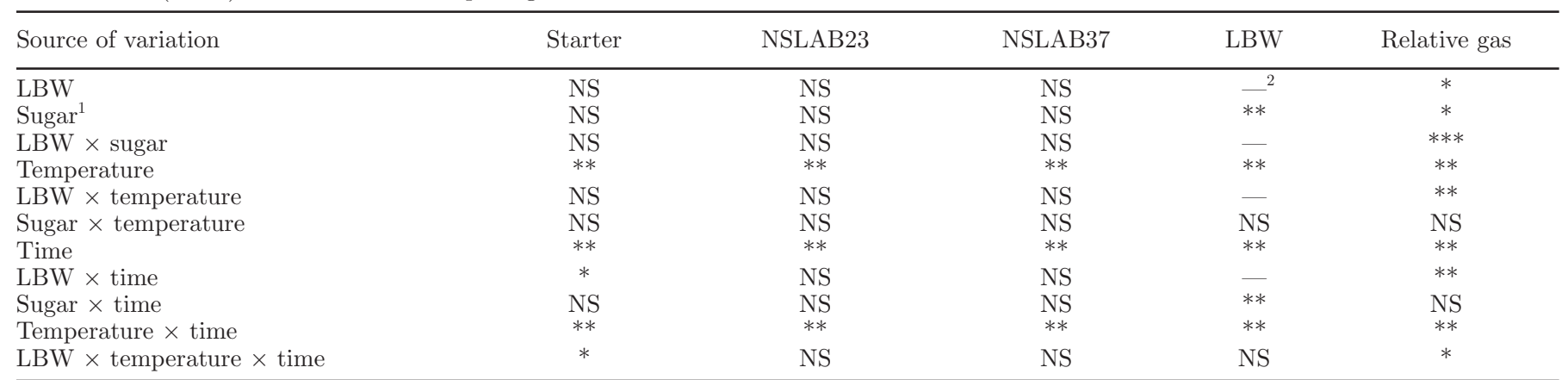

${ }^{1}$ Cheese curd with no sugar, $0.5 \%$ ribose, $0.5 \%$ galactose, or $0.25 \%$ ribose plus $0.25 \%$ galactose.

${ }^{2}$ Cheese made without added $L b$. wasatchensis was not included in the statistical analysis.

${ }^{*} P<0.05 ;{ }^{* *} P<0.01 ;{ }^{* * *} 0.1>P>0.05 ; \mathrm{NS}=P>0.05$. 
creased more rapidly $(P<0.05)$ and reached higher levels $(P<0.05)$ in cheese ripened at $12^{\circ} \mathrm{C}$ (Figure 1 ). There were no significant direct or interactive effects of sugar supplementation or $L b$. wasatchensis addition on the numbers of NSLAB23 or NSLAB37 in cheese $(P>0.05)$. Initially, NSLAB numbers were $<10^{2} \mathrm{cfu} / \mathrm{g}$ and increased to $\geq 10^{7}$ and $10^{5}$ to $10^{6} \mathrm{cfu} / \mathrm{g}$ during 16 wk of ripening at 12 and $6^{\circ} \mathrm{C}$, respectively. The highest growth occurred within the first 8 wk of ripening at both 6 and $12^{\circ} \mathrm{C}$. Within each temperature, NSLAB numbers were the same between 8 and 16 wk of ripening $(P>0.05)$, with significantly lower counts at $6^{\circ} \mathrm{C}$ $(P<0.05)$.

The increase in NSLAB counts in cheeses at higher ripening temperature $\left(12^{\circ} \mathrm{C}\right)$ is in agreement with previous observations for ripening of full-fat Cheddar cheese (Cromie et al., 1987; Jordan and Cogan, 1993; Lane et al., 1997; Fenelon et al., 1999). It was interest-
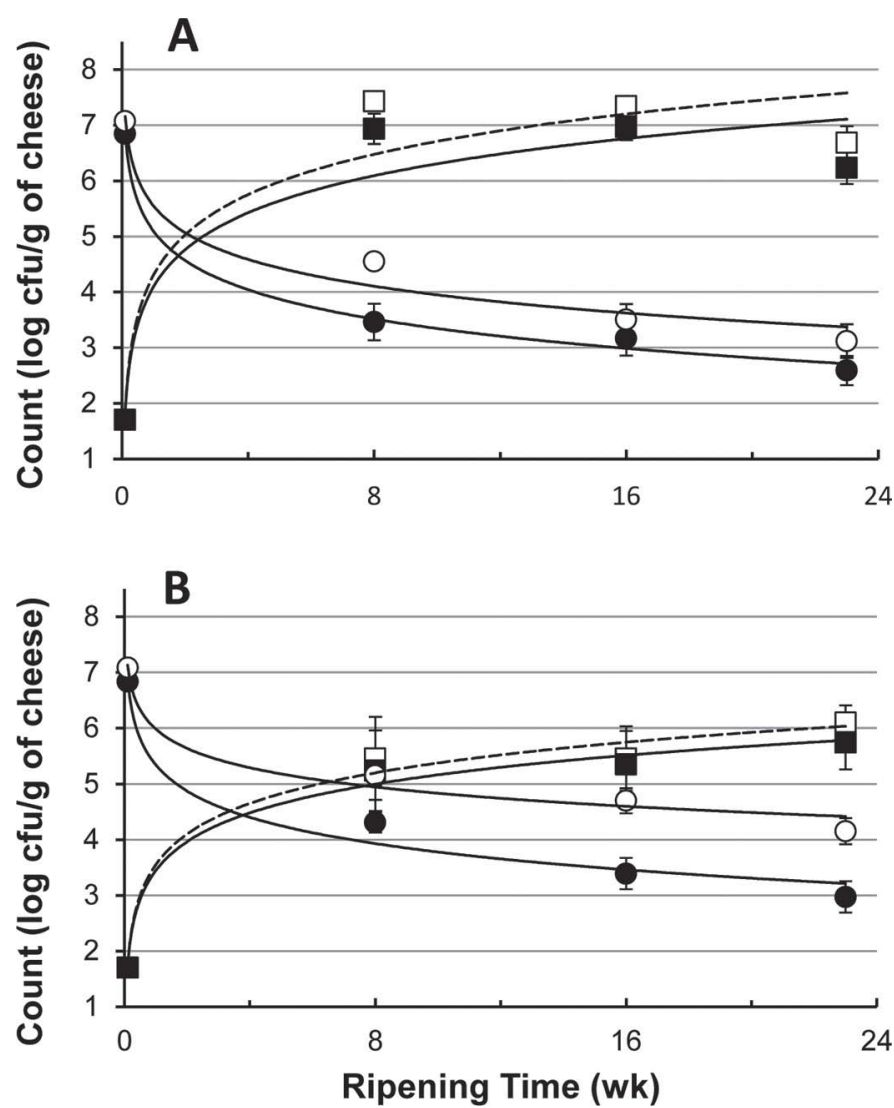

Figure 1. Changes in microbiota during storage of Cheddar cheese at (A) $12^{\circ} \mathrm{C}$ and (B) $6^{\circ} \mathrm{C}$ showing decrease in starter lactococci without (O) and with $(-)$ addition of Lactobacillus wasatchensis (pooled means over all sugar treatments) and increase in nonstarter lactic acid

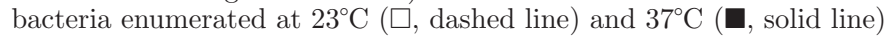
(pooled over all treatments) with associated best-fit trend lines. Bars $=\mathrm{SE}(\mathrm{n}=12$ for starter lactococci and $\mathrm{n}=24$ for nonstarter lactic acid bacteria).
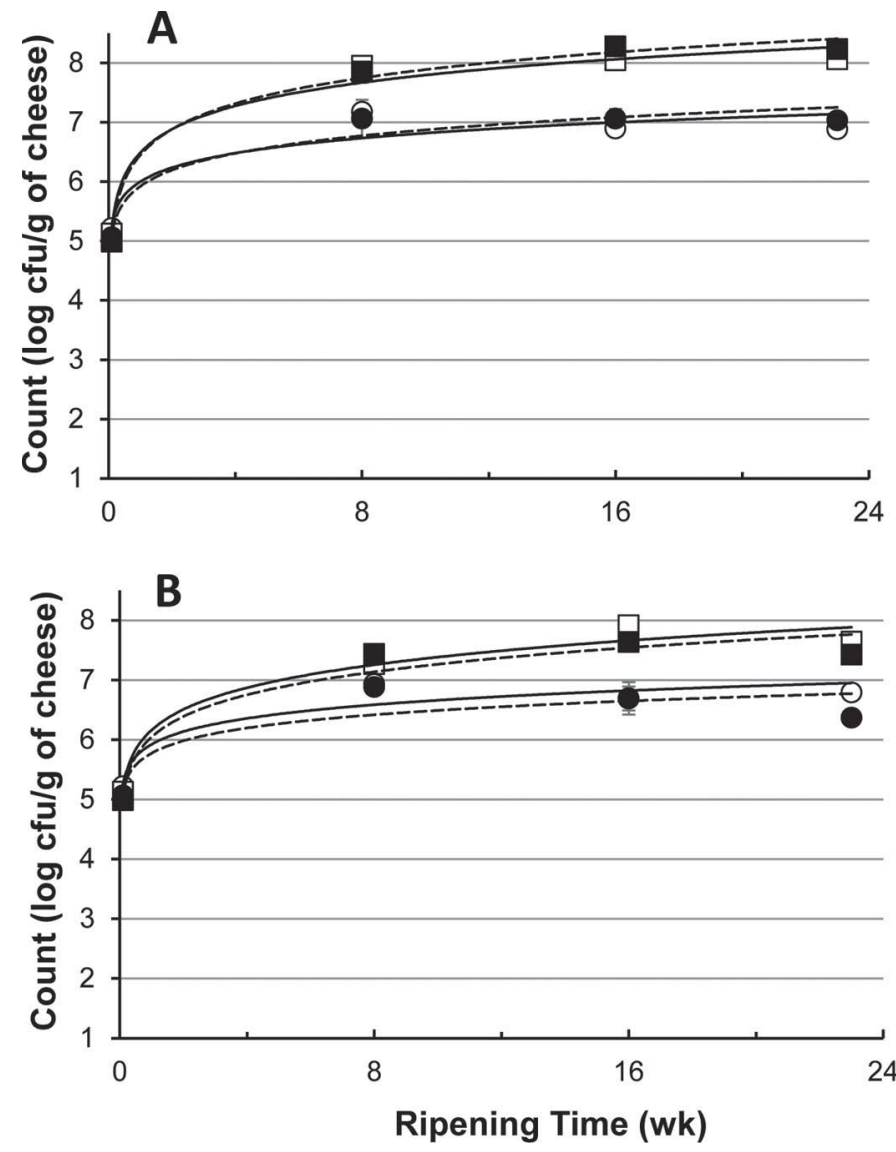

Figure 2. Increase in Lactobacillus wasatchensis during storage of Cheddar cheese at (A) $12^{\circ} \mathrm{C}$ and (B) $6^{\circ} \mathrm{C}$, control (no added sugars) cheese $(\bigcirc$, solid line), and cheeses with $0.5 \%$ ribose added $(\square$, solid line), $0.5 \%$ galactose added ( $\bullet$, dashed line), and $0.25 \%$ ribose and $0.25 \%$ galactose added ( $\mathbf{\square}$, dashed line) with associated best-fit trend lines. Bars $=\mathrm{SE}(\mathrm{n}=3)$.

ing that there were significant differences $(P<0.05)$ in NSLAB numbers when enumerated on MRS-R-V at $23^{\circ} \mathrm{C}$ (i.e., NSLAB23) compared with being enumerated on MRS-V at $37^{\circ} \mathrm{C}$ (i.e., NSLAB37; Figure 1). Whether this is because there are other NSLAB that do not grow rapidly at $37^{\circ} \mathrm{C}$ or that require ribose for rapid growth is unclear. It does suggest that the NSLAB population in Cheddar cheese is not as uniform as previously thought and that the common use of MRS (or MRS-V) incubated at $37^{\circ} \mathrm{C}$ for enumerating NSLAB bacteria in cheese should be revisited.

As in previous cheese-making experiments (McMahon et al., 2014), we observed some vat-to-vat variations in NSLAB levels, with most NSLAB counts reaching $10^{4}$ to $10^{6} \mathrm{cfu} / \mathrm{g}$ within $8 \mathrm{wk}$, whereas in other replicates, the NSLAB counts remained low $\left(\leq 10^{2} \mathrm{cfu} / \mathrm{g}\right)$ for up to 16 wk. However, NSLAB numbers in all replicates reached $10^{4}$ to $10^{7} \mathrm{cfu} / \mathrm{g}$ after $23 \mathrm{wk}$ of ripening. Such differences in cheese biota (especially in indigenous NSLAB 
populations) within an individual cheese manufacturing facility have been reported previously (Broadbent et al., 2003; Oberg et al., 2011). This can arise from differences in cleaning and sanitation of cheese vats as well as differences in the cheese-making history of the vats (i.e., what cheeses had been made and what cultures had previously been used in the vats). It may also be a reflection of there being multiple strains of indigenous NSLAB in the cheese microbiota during ripening (Beuvier and Duboz, 2014).

\section{Organic Acids}

Pooled means for organic acids after 16 wk ripening showed that concentrations of lactic, acetic, propionic, pyruvic, formic, and orotic acids increased in all cheeses, whereas citric acid decreased $(P<0.05$; Table 2$)$. No significant differences could be attributed to adding ribose or galactose into cheese curd, and ripening temperature was the only main level significant factor influencing levels of lactic, acetic, and propionic acids (Table 1).

There was only a small increase in lactic acid during ripening, reaching $1.13 \%$ after $16 \mathrm{wk}$, whereas propionic acid levels significantly increased during $16 \mathrm{wk}$ from an initial 0.08 to $0.21 \%$ and $0.42 \%$ at 6 or $12^{\circ} \mathrm{C}$, respectively (Table 2). The increase at $6^{\circ} \mathrm{C}$ storage was similar to the findings of McMahon et al. (2014), who reported a 3 -fold increase after 3 -mo storage of Cheddar cheese. The 2-fold-higher propionic acid levels at $12^{\circ} \mathrm{C}$ compared with $6^{\circ} \mathrm{C}$ were concomitant with higher numbers of NSLAB in cheese ripened at $12^{\circ} \mathrm{C}$ (see Figure 1). Such NSLAB activity has been reported to increase propionic acid levels in cheese during storage (St-Gelais et al., 1991; Bouzas et al., 1993). Lactobacillus curvatus has been identified as the dominant NSLAB in cheese made at Utah State University (Broadbent et al., 2013) and genomic data suggest it has the metabolic capability to produce propionic acid (J. Broadbent, unpublished data).

Acetic acid levels were significantly affected by time and by the temperature $\times$ time interaction with higher levels obtained at the elevated ripening temperature (Table 2). No significant increase was observed at $6^{\circ} \mathrm{C}(P>0.05)$, whereas a 7 -fold increase at $12^{\circ} \mathrm{C}$ occurred after 16 wk of ripening $(P<0.05)$. Lues and Bekker (2002) reported that acetic acid concentration in Cheddar cheese initially decreased rapidly and then increased after $3 \mathrm{wk}$ of storage, whereas Upreti et al. (2006b) reported a decrease in acetic acid content during the first few months of storage from an initial concentration of 0.15 to $0.06 \mathrm{~g} / \mathrm{kg}$. Surprisingly, adding ribose to cheese curd did not have a significant effect on acetic acid levels in any of the cheeses even though fermentation of pentoses by Group II and Group III LAB yields equimolar amounts of lactic acid and acetic acid, and a net 2 moles of ATP per mole of ribose consumed (Axelsson, 2004). Observing no differences in acetate levels in control versus ribose-supplemented cheeses could be due to the lysis of starter lactococci, which also releases ribose into the cheese microenvironment (Thomas, 1987).

Citric acid levels were significantly affected by time, Lb. wasatchensis $\times$ time, and sugar $\times$ time interactions (Table 2). Although statistically significant, there was only a minor decrease in citric acid during storage from initial 0.132 to $0.08 \%$ after 16 wk. Although citric acid levels were significantly affected by $L b$. wasatchensis over time, no citrate permease or citrate lyase encoding gene(s) were found in the genome (J. Broadbent and F. Ortakci, unpublished data). Formic, uric, and orotic acids also significantly increased during ripening $(P<$ $0.05)$.

\section{Cheese with Added Lb. wasatchensis}

As stated above, adding Lb. wasatchensis before cheesemaking had a significant effect on starter lactococci levels. However, NSLAB counts were not significantly affected by adding $L b$. wasatchensis (Table 4 ). Lactobacillus wasatchensis numbers increased by 3 logs during ripening, and the extent of growth was influenced by both ripening temperature and sugar supplementation. Faster growth occurred at $12^{\circ} \mathrm{C}$ (Figure 2), which was expected because its optimum growth rate occurs at $\sim 23^{\circ} \mathrm{C}$ (Ortakci et al., 2015). Most growth of $L b$. wasatchensis occurred during the first 8 wk of ripening with higher overall counts $(P<0.05)$ achieved at $12^{\circ} \mathrm{C}$ and when ribose (alone or with galactose) was added to the cheese curd. The final numbers reached after $23 \mathrm{wk}$ of ripening in cheese containing ribose or ribose plus galactose were the same $(P>0.05)$. Adding galactose on its own to the cheese curd did not $(P>0.05)$ increase growth of $L b$. wasatchensis compared with cheese with no added sugars (Figure 2). Similar growth on cheese with ribose and ribose plus galactose is in accordance with previous observations that $L b$. wasatchensis can co-utilize galactose when ribose is present (Ortakci et al., 2015) to maximize its growth in cheese.

In the control cheese with no added $L b$. wasatchensis, there were still $L b$. wasatchensis in the cheese, which in some replicates reached levels of $10^{5}$ to $10^{7} \mathrm{cfu} / \mathrm{g}$ after 16 to $23 \mathrm{wk}$, especially when the cheese was stored at $12^{\circ} \mathrm{C}$. Lactobacillus wasatchensis is indigenous to the facility in which the cheese was manufactured but we were not able to enumerate it before $16 \mathrm{wk}$ - the threshold for detection of $L b$. wasatchensis requires its numbers to be within $1.5 \mathrm{log}$ of the faster-growing 
NSLAB that initially appear on the MRS-R-V agar. At population levels below this threshold, the plates contain too many fast-growing colonies to distinguish and count any slower-growing colonies that may appear after the initial 2-d incubation. We speculate that because $L b$. wasatchensis grows slower than the predominant NSLAB in cheese, under normal cheese ripening conditions, it usually takes 4 to 6 mo to achieve similar levels and be enumerated.

In cheeses made from milk with added $L b$. wasatchensis, we were able to count $L b$. wasatchensis throughout the $23 \mathrm{wk}$ of ripening because the initial level of Lb. wasatchensis was $\sim 10^{5} \mathrm{cfu} / \mathrm{g}$ and, therefore, above the threshold compared with other NSLAB. Even though slower growing compared with $L b$. curvatus, $L b$. wasatchensis grew to $>10^{6}$ and $10^{7} \mathrm{cfu} / \mathrm{g}$ after 8 wk at 6 and $12^{\circ} \mathrm{C}$, respectively.

\section{Relative Gas}

All treatments (sugar treatment, addition of $L b$. wasatchensis, storage temperature, and time) significantly affected relative gas formation in cheese (Table 4). The interaction terms involving time, temperature, and $L b$. wasatchensis addition were also significant. Gas formation was significantly higher $(P<0.05)$ in cheese containing added $L b$. wasatchensis compared with control cheese at both ripening temperatures (Figure 3), whereas no gas formation was observed by $23 \mathrm{wk}$ at $6^{\circ} \mathrm{C}$ in the control cheese. Similarly, Laleye et al. (1990) found that adding OHF species such as Lb. brevis or $L b$. fermentum during cheese making resulted in open texture in cheese after 2 mo of ripening, whereas no openness was observed in a control cheese. It has also been recognized that gas formation can occur in cheese without any openness being observed because $\mathrm{CO}_{2}$ does have some solubility in the aqueous phase of cheese (Laleye et al., 1987).

Interactions involving sugar addition were not significant except there was a tendency $(P=0.073)$ for the sugar $\times L b$. wasatchensis interaction to influence gas production (Table 4). When pooled over time and temperature, relative gas production based on sugar and Lb. wasatchensis addition was significantly higher when $0.25 \%$ ribose plus $0.25 \%$ galactose was added compared with adding either galactose or ribose alone, or the no-sugar-added control. The highest gas formation occurred in cheese containing added $L b$. wasatchensis as well as ribose and galactose $(P<0.05$; Figure 3$)$. In these cheeses, the presence of ribose supported growth of $L b$. wasatchensis to high numbers and presence of galactose enabled OHF fermentation with $\mathrm{CO}_{2}$ release. When only ribose was added to the cheese, there was more growth of the Lb. wasatchensis but less gas forma- tion $(P<0.05)$ because OHF bacteria do not produce $\mathrm{CO}_{2}$ from pentoses (Axelsson, 2004).

Gas formation during storage was significantly higher at $12^{\circ} \mathrm{C}$ than at $6^{\circ} \mathrm{C}(P<0.05)$. This was expected as elevated ripening temperatures can increase the occurrence of openness in cheese (Elliott et al., 1981; Laleye et al., 1987). At both 6 and $12^{\circ} \mathrm{C}$, there was growth of Lb. wasatchensis, with levels being about 0.5 log higher at $12^{\circ} \mathrm{C}$. This increased growth at the elevated storage temperature could account for the higher measurements of relative gas formation, but solubility of $\mathrm{CO}_{2}$ may also be a factor. At $6^{\circ} \mathrm{C}$, there is higher solubility of $\mathrm{CO}_{2}$ compared with $12^{\circ} \mathrm{C}$ (CRC Handbook of Chemistry and Physics, 2009). Thus, even with the same level of gas production, there would be more $\mathrm{CO}_{2}$ present in the gaseous state at $12^{\circ} \mathrm{C}$ (evident as looser packs) and more probability of openness as well, occurring as slit and crack formation in the cheese. This was confirmed when a $L b$. wasatchensis-treated cheese with no apparent gas production (i.e., a tight pack) was moved from $6^{\circ} \mathrm{C}$ to room temperature $\left(\sim 22^{\circ} \mathrm{C}\right)$ and after a while the package became loose (data not shown).

The possibility that slow-growing bacteria may contribute to late blowing in Cheddar cheese has been previously hypothesized (Elliott et al., 1981). In that study, the bacterium was not identified (except for being a slow-growing, salt-tolerant, non-spore-forming, heat-tolerant, gram-positive rod), but its addition to cheese milk at $10^{1}$ and $10^{4} \mathrm{cfu} / \mathrm{mL}$ resulted in gas formation during storage at $10^{\circ} \mathrm{C}$ but not at $4.5^{\circ} \mathrm{C}$. With Lb. wasatchensis, most of the growth occurs during the first 8 wk of ripening, whereas observations of gas production in cheese usually occur after this time. This suggests that growth is being supported by pentoses available in the cheese and production of $\mathrm{CO}_{2}$ occurs

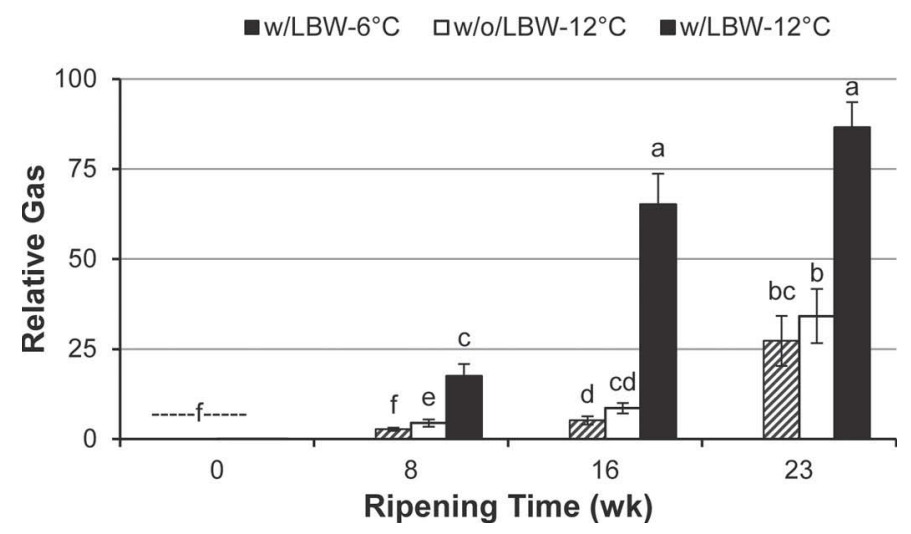

Figure 3. Pooled means of relative gas formation in Lactobacillus wasatchensis inoculated cheese (w/LBW) or un-inoculated control cheese $(\mathrm{w} / \mathrm{o} / \mathrm{LBW})$ during $23 \mathrm{wk}$ storage at $6^{\circ} \mathrm{C}$ or $12^{\circ} \mathrm{C}$. Bars with the same letter (a to f) were not significantly different $(\alpha=0.05)$; error bars $=\mathrm{SE}(\mathrm{n}=12)$. 
after the pentoses are consumed but while there are fermentable hexoses still present. There also needs to be sufficient $\mathrm{CO}_{2}$ produced to exceed its solubility in cheese and then loosening of the pack may be observed.

Fermentation of citric acid can also result in $\mathrm{CO}_{2}$ production in cheese by NSLAB (Overcast and Albrecht, 1952) although in our study there was only a relatively low level, with $0.13 \%$ present after pressing, decreasing to $0.08 \%$ during storage, with no differences occurring because of sugar addition or ripening temperature. Hoglund et al. (1972) also reported that substrates other than citrate could cause $\mathrm{CO}_{2}$-related openness in cheese.

\section{Growth of Lb. wasatchensis on Starter Cell Lysate}

Production of a cell lysate using bead beating was successful in producing a supernatant containing $\sim 4$ $\mathrm{mg} / \mathrm{mL}$ protein with a reduction in starter lactococci from $\sim 10^{10}$ to $<5 \times 10^{4} \mathrm{cfu} / \mathrm{mL}$. After centrifuging to produce a cell-free lysate and adding it to carbohydratefree MRS, the growth of $L b$. wasatchensis reached high cell densities (with an $\mathrm{OD}_{600}$ up to 2.49) after $10 \mathrm{~d}$ incubation (initial $\mathrm{OD}_{600} \sim 0.16$ ). In contrast, very little growth occurred (only 0.06 increase in $\mathrm{OD}_{600}$ ) in the control when no lysate was added (Figure 4).

Although growth of $L b$. wasatchensis in cell lysate was slower compared with that on MRS plus $1 \%$ ribose (Ortakci et al., 2015), final cell densities reached were considerably higher in the lysate. This likely explains the 2-log increase in Lb. wasatchensis counts in cheese without any added sugars during the time when starter counts decreased from $10^{7}$ to $\sim 10^{4} \mathrm{cfu} / \mathrm{g}$ (see Figures 1 and 2). Along with Lb. wasatchensis, the other fastergrowing NSLAB increased concomitantly with this decrease in starter lactococci counts (see Figure 2) and probably utilized the same sugars (such as ribose and $\mathrm{N}$-acetyl amino sugars) being released during autolysis of starter cells (Thomas, 1987; Fox et al., 1998). Of these released sugars, ribose is considered the most readily released from starter lactococci (Thomas, 1987; Rapposch et al., 1999). Lactobacillus brevis, another OHF species, has been shown to reach higher cell densities on lactococcal cell lysate than many other NSLAB (Thomas, 1987). Similarly, Lb. paracasei has been observed to grow to $10^{7} \mathrm{cfu} / \mathrm{mL}$ from an initial level of $10^{2} \mathrm{cfu} / \mathrm{mL}$ in lysate of Lactobacillus helveticus (Rapposch et al., 1999). Another source of nutrients to support growth of NSLAB in cheese is that associated with the milk fat globule membrane material (Moe et al., 2013). Thus, there is clearly an adequate supply of carbohydrate material from autolysis-released products of starter cells or the components themselves to

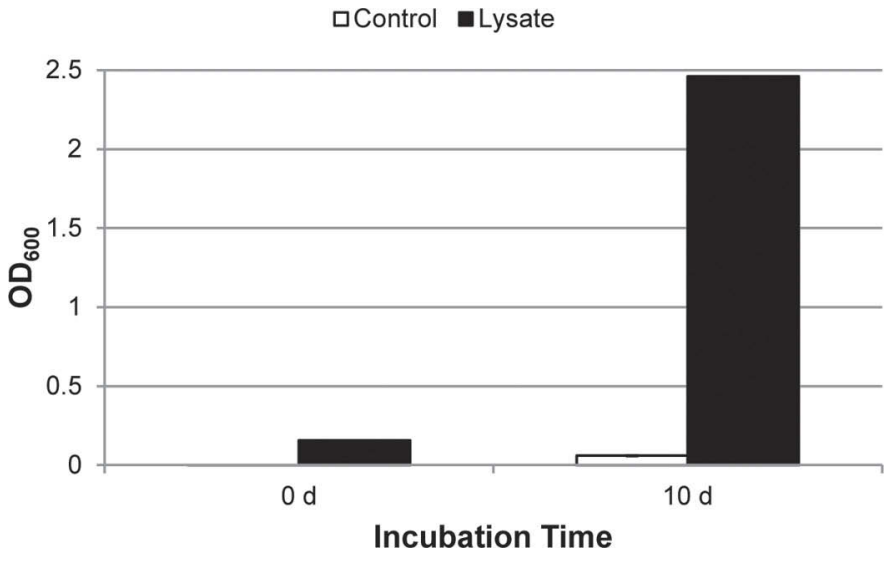

Figure 4. Growth of Lactobacillus wasatchensis as measured by optical density at $600 \mathrm{~nm}\left(\mathrm{OD}_{600}\right)$ in carbohydrate-free de Man, Rogosa, and Sharpe (MRS) broth containing starter cell lysate (ם) or sterile water as control $(\square)$ during anaerobic incubation at $23^{\circ} \mathrm{C}$ at 0 and 10 d. Bars $=\operatorname{SE}(\mathrm{n}=3)$.

support growth of $L b$. wasatchensis and other NSLAB during cheese ripening.

\section{CONCLUSIONS}

This study explored the growth in cheese of a novel, slow-growing OHF NSLAB, Lb. wasatchensis sp. nov., on late gas formation. This NSLAB uses galactose very slowly in the absence of ribose, and fermentation of galactose (or other fermentable hexose) as an energy source causes $\mathrm{CO}_{2}$ production. Adding ribose to cheese curd stimulated the growth of $L b$. wasatchensis during cheese ripening over 23 wk with most of the growth occurring during the first $8 \mathrm{wk}$ when there is a large decrease in starter lactococci numbers. Lactobacillus wasatchensis grows well using cell lysate as its carbon source, presumably because of release of ribose and other sugars. The likelihood of gas formation in cheese increases when a temperature such as $12^{\circ} \mathrm{C}$ is used to accelerated ripening. Having a combination of ribose and galactose in the cheese also increased gas production. Co-utilization of galactose with ribose by $L b$. wasatchensis appears to increase the occurrence and extent of late gas formation in cheese. Initially, ribose is consumed to promote growth with co-utilization of galactose, and then when ribose is depleted, the remaining galactose is used to produce energy, with $\mathrm{CO}_{2}$ being generated. Even without ribose supplementation, there was a $2-\log$ growth in $L b$. wasatchensis indicating that starter cell autolysis provides adequate pentoses to support growth. Enumerating Lb. wasatchensis in cheese is still problematic as it needs to be present at numbers within $1.5 \log$ of the faster growing NSLAB to be detectable on MRS-R-V agar. 


\section{ACKNOWLEDGMENTS}

The authors thank Lloyd Metzger, Midwest Dairy Foods Research Center, South Dakota State University (Brookings) for sugar and organic acids analysis and Bioenergy Life Science Inc. (Ham Lake, MN) for donation of ribose. This research was performed as part of the cheese applications program at the Western Dairy Center and supported by the National Dairy Council (Rosemont, IL) and the Utah Agricultural Experiment Station, Utah State University, and is approved as journal paper no. 8766. The use of trade names in this publication does not imply endorsement by Utah State University of the products named or criticism of similar ones not mentioned.

\section{REFERENCES}

Agarwal, S., D. McCoy, W. Graves, P. D. Gerard, and S. Clark. 2011. Sodium content in retail Cheddar, Mozzarella, and process cheeses varies considerably in the United States. J. Dairy Sci. 94:16051615.

Anonymous. 2015. Lactobacilli MRS agar, Lactobacilli MRS broth. Accessed Feb. 12, 2015. https://www.bd.com/europe/regulatory/ Assets/IFU/Difco_BBL/288110.pdf.

Axelsson, L. T. 2004. Lactic acid bacteria: Classification and physiology. Pages 1-63 in Lactic Acid Bacteria. S. Salminen and A. von Wright, ed. Marcel Dekker, New York, NY.

Beuvier, E., and G. Duboz. 2014. The microbiology of traditional hard and semihard cooked mountain cheeses. Pages 133-150 in Cheese and Microbes. C. W. Donnelly, ed. ASM Press, Washington, DC.

Bouzas, J., C. A. Kantt, F. Bodyfelt, and J. A. Torres. 1993. Time and temperature influence on chemical aging indicators for a commercial Cheddar cheese. J. Food Sci. 58:1307-1313.

Branen, A. L., and T. W. Keenan. 1969. Growth stimulation of Lactobacillus species by lactic streptococci. Appl. Microbiol. 17:280-285.

Broadbent, J. R., C. Brighton, D. J. McMahon, N. Farkye, M. Johnson, and J. Steele. 2013. Microbiology of Cheddar cheese made with different fat contents using a Lactococcus lactis single-strain starter. J. Dairy Sci. 96:4212-4222.

Broadbent, J. R., K. Houck, M. E. Johnson, and C. J. Oberg. 2003. Influence of adjunct use and cheese microenvironment on nonstarter bacteria in reduced-fat Cheddar-type cheese. J. Dairy Sci. 86:2773-2782.

CRC Handbook of Chemistry and Physics. 2009. 90th ed. D. R. Lide, ed. CRC Press, Boca Raton, FL.

Cromie, S. J., J. E. Giles, and J. R. Dulley. 1987. Effect of elevated ripening temperatures on the microflora of Cheddar cheese. J. Dairy Res. 54:69-76.

Donnely, C., C. Golnazarian, and K. Boor. 2014. Slit defect in Cheddar cheese. Accessed Jun. 21, 2015. http://www.powershow. com/view/1e1e6-MzVlN/Slit_Defect_in_Cheddar_Cheese_ powerpoint_ppt_presentation.

Elliott, J. A., G. E. Millard, and R. A. Holley. 1981. Late gas defect in Cheddar cheese caused by an unusual bacterium. J. Dairy Sci. 64:2278-2283.

Fenelon, M. A., M. P. Ryan, M. C. Rea, T. P. Guinee, R. P. Ross, C. Hill, and D. Harrington. 1999. Elevated temperature ripening of reduced fat cheddar made with or without lacticin 3147 starter culture. J. Dairy Sci. 82:10-22.

Folkertsma, B., P. F. Fox, and P. L. H. McSweeney. 1996. Accelerated ripening of Cheddar cheese at elevated temperatures. Int. Dairy J. 6:1117-1134.
Fox, P. F., J. A. Lucey, and T. M. Cogan. 1990. Glycolysis and related reactions during cheese manufacture and ripening. Crit. Rev. Food Sci. Nutr. 29:237-253.

Fox, P. F., P. L. H. McSweeney, and C. M. Lynch. 1998. Significance of non-starter lactic acid bacteria in Cheddar cheese. Aust. J. Dairy Technol. 53:83-89.

Golnazarian, C. 2001. Slit formation in Cheddar cheese: A comprehensive investigation of the microbiological parameters associated with this defect. PhD Thesis. University of Vermont, Burlington.

Hoglund, G. F., T. F. Fryer, and J. Gilles. 1972. The influence of lactobacilli on open texture in Cheddar cheese. N.Z. J. Dairy Sci. Tech. 7:159-160.

Jordan, K. N., and T. M. Cogan. 1993. Identification and growth of non-starter lactic acid bacteria in Irish Cheddar cheese. Ir. J. Agric. Food Res. 32:47-55.

Laleye, L. C., R. E. Simard, B. H. Lee, R. A. Holley, and R. N. Giroux. 1987. Involvement of heterofermentative lactobacilli in development of open texture in cheeses. J. Food Prot. 50:1009-1012.

Laleye, L. C., R. E. Simard, B. H. Lee, R. A. Holley, and R. N. Giroux. 1990. Quality attributes of Cheddar cheese containing added lactobacilli. J. Food Sci. 55:114-118.

Lane, C. N., P. F. Fox, E. M. Walsh, B. Folhersma, and P. L. H. McSweeney. 1997. Effect of compositional and environmental factors on the growth of indigenous non-starter lactic acid bacteria in Cheddar cheese. Lait 77:561-573.

Lawrence, R. C., J. Gilles, and L. K. Creamer. 1993. Cheddar cheese and related dry-salted cheese varieties. Pages 1-38 in Cheese: Chemistry, Physics and Microbiology. Vol. 2. Major Cheese Groups. 2nd ed. P. F. Fox, ed. Chapman \& Hall, London, UK.

Lawrence, R. C., J. Gilles, L. K. Creamer, V. L. Crow, H. A. Heap, C. G. Honoré, K. A. Johnston, and P. K. Samal. 2004. Cheddar cheese and related dry-salted cheese varieties Page 72 in Cheese: Chemical, Physics and Microbiology. Vol. 2. 3rd ed. P. F. Fox, T. M. Cogan, and T. P. Guinee, ed. Elsevier Ltd., London, UK.

Lues, J. F. R., and A. C. M. Bekker. 2002. Mathematical expressions for organic acids in early ripening of a Cheddar cheese. J. Food Compos. Anal. 15:11-17.

Martley, F. G., and V. L. Crow. 1996. Open texture in cheese: The contributions of gas production by microorganisms and cheese manufacturing practices. J. Dairy Res. 63:489-507.

McMahon, D. J., C. J. Oberg, M. A. Drake, N. Farkye, L. V. Moyes, M. R. Arnold, B. Ganesan, J. Steele, and J. R. Broadbent. 2014. Impact of sodium, potassium, magnesium, and calcium salt cations on $\mathrm{pH}$, proteolysis, organic acids, and microbial populations during storage of full fat Cheddar cheese. J. Dairy Sci. 97:4780-4798.

McSweeney, P. L. H., and P. F. Fox. 2004. Metabolism of residual lactose and of lactate and citrate. Pages 361-372 in Cheese: Chemistry, Physics and Microbiology, Vol. 1: General Aspects. 3rd ed. P. F. Fox P. L. H. McSweeney, T. M. Cogan, and T. P. Guinee, ed. Elsevier, London, UK.

Michel, V., and F. G. Martley. 2001. Streptococcus thermophilus in Cheddar cheese-Production and fate of galactose. J. Dairy Res. $68: 317-325$.

Moe, K. M., D. Porcellato, and S. Skeie. 2013. Metabolism of milk fat globule membrane components by nonstarter lactic acid bacteria isolated from cheese. J. Dairy Sci. 96:727-739.

Mullan, W. M. A. 2000. Causes and control of early gas production in Cheddar cheese. Int. J. Dairy Technol. 53:63-68.

Oberg, C. J., L. V. Moyes, M. J. Domek, C. F. Brothersen, and D. J. McMahon. 2011. Survival of probiotic adjunct cultures in cheese and challenges in their enumeration using selective media. J. Dairy Sci. 94:2220-2230.

Oberg, C. J., T. S. Oberg, M. D. Culumber, F. Ortakci, J. R. Broadbent, and D. J. McMahon. 2015. Lactobacillus wasatchensis sp. nov., a non-starter lactic acid bacteria isolated from aged Cheddar cheese. Int. J. Syst. Evol. Microbiol. (Accepted for publication).

Olson, N. F., and M. E. Johnson. 1990. Light cheese products: Characteristics and economics. Food Technol. 44:93-96.

Ortakci, F., J. R. Broadbent, C. J. Oberg, and D. J. McMahon. 2015. Growth and gas production of a novel obligatory heterofermenta- 
tive Cheddar cheese nonstarter lactobacilli species on ribose and galactose. J. Dairy Sci. 98:3645-3654.

Overcast, W. W., and T. W. Albrecht. 1952. Gas production in Cheddar cheese caused by Leuconostoc citrovorum. J. Dairy Sci. 35:554558.

Peterson, S. D., and R. T. Marshall. 1990. Nonstarter lactobacilli in Cheddar cheese: A review. J. Dairy Sci. 73:1395-1410.

Phadungath, C. 2011. The efficacy of sodium gluconate as a calcium lactate crystal inhibitor in cheddar cheese. PhD Thesis. South Dakota State University, Brookings.

Rapposch, S., F. Eliskases-Lechner, and W. Ginzinger. 1999. Growth of facultatively heterofermentative lactobacilli on starter cell suspensions. Appl. Environ. Microbiol. 65:5597-5599.

Richardson, G. H., ed. 1985. Page 351 in Standard Methods for the Examination of Dairy Products. 15th ed. Am. Publ. Health Assoc., Washington, DC

Sherwood, I. R. 1939. The relation of certain lactic acid bacteria to open texture in Cheddar cheese. J. Dairy Res. 10:326-335.

St-Gelais, D., G. Doyon, J. R. Rolland, and J. Goulet. 1991. Sugar and organic acid concentrations during ripening of Cheddar cheese-like products. Milchwissenschaft 46:288-291.

Thomas, T. D. 1987. Cannibalism among bacteria found in cheese. N.Z. J. Dairy Sci. Technol. 22:215-219.

Thomas, T. D., and K. N. Pearce. 1982. Influence of salt on lactose fermentation and proteolysis in Cheddar cheese. N.Z. J. Dairy Sci. Technol. 16:253-259.
Tinson, W., M. F. Ratcliff, A. J. Hillier, and G. R. Jago. 1982. Metabolism of Streptococcus thermophilus. 3. Influence on the level of bacterial metabolites in Cheddar cheese. Aust. J. Dairy Technol. $37: 17-21$.

Turner, K. W., and T. D. Thomas. 1980. Lactose fermentation in Cheddar cheese and the effect of salt. N.Z. J. Dairy Sci. Technol. 15:265-276.

Upreti, P., L. E. Metzger, and K. D. Hayes. 2006a. Influence of calcium and phosphorus, lactose, and salt-to-moisture ratio on Cheddar cheese quality: Proteolysis during ripening. J. Dairy Sci. 89:444453.

Upreti, P., L. L. McKay, and L. E. Metzger. 2006b. Influence of calcium and phosphorus, lactose, and salt-to-moisture ratio on Cheddar cheese quality: Changes in residual sugars and water-soluble organic acids during ripening. J. Dairy Sci. 89:429-443.

Van Slyke, L. L., and E. B. Hart. 1903. The relation of carbon dioxide to proteolysis of ripening Cheddar cheese. New York (Geneva) Agric. Expt. Sta. Bull. 231:20-41. (Cited in Tretsven, 1945. Study of the gas evolution from ripening cheddar cheese. $\mathrm{PhD}$ Thesis. Graduate School of University of Wisconsin).

Wilkinson, M. 1993. Acceleration of cheese ripening. Pages 523-555 in Cheese: Chemistry, Physics and Microbiology. Vol. 1. 2nd ed. P. F. Fox, ed. Chapman and Hall Publishers, London, UK.

Wilkinson, M. G., T. P. Guinee, D. M. O'Callaghan, and P. F. Fox. 1994. Autolysis and proteolysis in different strains of starter bacteria during Cheddar cheese ripening. J. Dairy Res. 61:249-262. 